\title{
Quantitative Approach towards Genealogical Relationship of South Halmahera Languages Group
}

\author{
Jumahir Jamulia \\ State Institute for Islamic Studies (IAIN) Ternate
}

\begin{abstract}
This paper aims to investigate genealogical relationship of South Halmahera languages quantitatively by applying lexicostatistics. The method of this study is field linguistic or fieldwork (Samarin, 1967) to eight villages represented the eight languages in this study by using Sulawesi Umbrella wordlist consists of more than 400 words as an instruments in collecting linguistic data. The data was then analyzed by applying WordSurv ver.7, where its result is useful in setting up language subgroup and family tree. The result of the study implies that the degree of relationship between languages of Sawai-Gebe-Buli-Maba-Patani and languages of GaneEast Makian are 'languages of family'; while Irarutu is 'family of stock'.
\end{abstract}

Keywords: quantitative, genealogical, relationship, South Halmahera languages

\section{Introduction}

This paper aims to study genealogical relationship of South Halmahera languages, found along the southeast coast of the island of Halmahera in the Indonesian province of North Maluku, and a language is spoken in the east of the Bomberai Peninsula in West Papua province.

According to Lewis, Simons, \& Fennig (2014) the member of the South Halmahera languages are Gane, East Makian, Buli, Maba, Patani, Sawai, and Irarutu. In this research, Gebe (a language of Raja Ampat) is also included by considering its geographic proximity and lexical relatedness toward South Halmahera languages, i.e. Gebe has 44\% lexical similarity with Patani (Lewis, Simons, \& Fennig, 2014). Therefore, it needs to be proved scientifically to explain the relationship between Gebe and South Halmahera languages.

Among the South Halmahera languages, Irarutu is a debated language. Anceaux (1961), Blust (1993), and Kamholz (2014) exclude Irarutu from SHWNG. Blust (1993:271) claims that the exclusion of Irarutu was based on information from the late Professor J. C. Anceaux (1961). However, Ross (1995) attempts to classify Irarutu and argues that contras with Blust (1993). For Ross, Irarutu belongs in SHWNG, particularly of South Halmahera.

Collins (1983:33) states that "Austronesian was the best described languages family after Finno-Urgic and IndoEuropean itself'. However there are many Austronesian languages, especially South Halmahera are small and poorly described, except Buli and Taba or East Makian (Blust, 2013:33)

As long as my extensive search on both historicalcomparative linguistics and South Halmahera languages studies, there is not any single study of South Halmahera languages which apply the principles of historicalcomparative linguistics, therefore, it is very important to conduct an extensive study which covers all the South Halmahera languages.
The main issue of this research is to establish the genealogical relationship degree of South Halmahera languages in order to fill the gap of research on historical linguistics in this field. However, this paper focusing only on quantitative approach by applying lexicostatistic.

\section{Literature Survey}

The work of historical comparative linguistics was first introduced by Sir William Jones in 1786 who stated about the similarity of Sanskrit, Greek, and Latin. In his famous speech, Jones presented the significant concepts to the understanding of changing in a language, namely the ideas of language relationship and proto-language (Crowley, 1987).

Research on this field has been done worldwide and progressively developed by West-Europe scholars since the nineteenth century, and they were successfully established the foundation of historical linguistics. According to Schendl (2001:16):

"The most famous and best-researched language family is the Indo-European family, containing languages which are spoken from India to the western borders of the European continent with a long textual tradition. Scholars have successfully grouped the languages into a number of subfamilies such as Germanic, Italic, Balto-Slavic, Celtic, Greek, and Indo-Iranian. They have also reconstructed Proto-Indo-European (Schendl, 2001:16).'

However, according to Collins (1983:1) Austronesian languages had been studied as early as 1708 . It was first signed by the study of Hadrian Reland who observed the linguistics similarities of many Indonesian languages, and followed by Lorenzo Hervas y Panduro who identified and established the Malayo-Polynesian family of languages in 1784, two years before Sir William Jones proposed his work, a parent of Indo-European language. The study of Austronesian languages, then, followed by the appearance of Wilhelm van Humboldt between 1836 and 1839 who sketched the history of the Austronesian languages. 


\section{International Journal of Science and Research (IJSR) \\ ISSN (Online): 2319-7064}

Index Copernicus Value (2013): 6.14 | Impact Factor (2014): 5.611

The earliest studies of Austronesian languages were then followed by the works of Franz Bopp (1840) who tried to show the hypothetical connection between Indo-European and Austronesian languages. However, H.N. van der Tuuk was the first scholar who tried to apply systematically and truly the principles of Indo-European comparative linguistics to Austronesian languages, through his work on comparative study of the Indonesian languages on Batak, Batavian Malay, Malagasy, Old Javanese and Balinese (cf. Collins, 1983:1).

The work of van der Tuuk inspired many scholars, for instances, Brandes (1884) who collected van der Tuuk works on Austronesian sounds correspondences and labeling them as van der Tuuk sound laws; Kern (1889) who wrote Austronesian homeland; and Brandstetter (1893) who undertook proto-Austronesian phonology, grammar and vocabulary (cf Collins, 1983:2).

By the comprehensive works of many scholars on Austronesian language in the nineteenth century, this makes Austronesian language was the best described language family after Finno-Ugric and Indo-European itself (Collins, 1983:2).

However, there are many minority or ethnic languages and enclaves of Austronesian languages have not been studied by applying historical-comparative principles, for instance, the languages grouped into South Halmahera-New West Guinea (henceforth SHNWG), particularly on South Halmahera languages. This condition is admitted by Blust who states that most of languages in this group are small and poorly described. The best-known SHWNG languages are Buli, Taba or East Makian and Numfor, which has served as a local trade language in coastal regions of western New Guinea for some centuries (Blust, 2013:33).

There is not exact number of SHWNG. Blust (2013:33) states that SHWNG is a collection of some 30-40 languages spoken in the northern Moluccas and adjacent parts of the north coast of the Bird's Head Peninsula of west New Guinea. On the other hand, Lewis, Simons, \& Fennig (2014) include 41 languages into SHWNG. But according to Kamholz (2014) the number of SHWNG consists of 42 languages, even down to 38 if Bomberai languages (Bedonas, Erokwanas, Irarutu, Kuri) are excluded from SHWNG.

The relationship of Maba, Patani and Weda has been established for centuries known as Gamrange (borrowed fron Tidore, means ,three villages ${ }^{e}$ ) with fagogoru (means ,love and brotherhood ') as their slogan. The awareness to love each other and keep maintaining the brotherhood among people of Gamrange derives from a shared genius knowledge that they come from the same ancestor.

Historically, the intense contact between people of Gamrange (Maba, Weda, and Patani) and people of Raja Ampat (Salawati, Waigeo, Misool, and Waigama) had been going on since the time of the Sultanate of Tidore, from which the Sultans of Tidore obtained vital support forces (Widjojo, 2009:3). Widjojo writes one of the tribute of Gamrange to the Sultanate as:
"In Maba, east Halmahera, tribute was paid in rice because Maba produced this crop. But Patani was supposed to deliver slaves in tribute....The people of Patani were absolved from this duty because they had to provide slaves for the Sultan, either captured or purchased from the Raja Ampat and Onin." (Widjojo, 2009: 50-51)

The contact between Gamrange and Raja Ampat in turn enables to language and cultural contact, and language spread due to people migration. An evidence of the contact can be seen in Yeisowo, a village on Patani district in which people have curly hair and striking Papuan features. The same evidence of people with Papuan features is also can be found on Tidore as being explained by van Staden (2000:10):

"On Tidore, there is still one village, Bobo, which used to be the slavese village. Indeed, in this village the majority of people have curly hair and striking Papuan features. However, in this village, as elsewhere, it is taboo to even suggest that the inhabitants were not originally from Tidore, but from the Bird's Head."

\subsection{Genealogical Relationship}

Languages classification into a group or a family may be based on genetics, diffusion, lexicostatistics, or other relationships. Despite Blake (2004:446) insists that both professional linguists and general readers find the genetic classification is the most satisfying way to group the languages. In addition, Bussmann (2006:183-184) proposes three classifications in grouping several languages together through (a) areal (geographical) classification, (b) genealogical (genetic) classification, and (c) typological classification. The explanation of language classifications from Bussmann is in the following:

"(a) areal (geographical) classification, based on linguistic similarities which have arisen from cultural contact between linguistic communities as well as geographical proximity through borrowing of words and grammatical constructions; (b) genealogical (genetic) classification, based on linguistic similarities that result from being descendants of a common proto-language; and (c) typological classification, based on structural similarities that are independent (Bussmann, 2006: 183-184)."

Due to time available and subject matter, the researcher focuses only on grouping South Halmahera languages through genealogical (genetic) classification under an umbrella of Historical Comparative Linguistics.

Trask (2005:69) states that genetic relationship is the relationship between languages which share a common ancestor. In addition, Bussmann (2006:184) states that genealogical (genetic) classification based on linguistic similarities that result from being descendants of a common proto-language.

Campbell also states that language family is a group of languages related through descent from a common ancestor, called the proto-language of that family (Campbell, 1999:111). Languages that derive from a common proto- 


\section{International Journal of Science and Research (IJSR) \\ ISSN (Online): 2319-7064}

Index Copernicus Value (2013): 6.14 | Impact Factor (2014): 5.611

language or common ancestor are called language families, e.g. the Austronesian languages, the Indo-European languages.

There are several factors cause language resemblances or similarities. Aikhenvald \& Dixon (2006:1) state that two languages can resemble each other (a) in the categories, constructions and types of meaning they use; and (b) in the forms they employ to express these. Forston (2004:3), Aikhenvald \& Dixon (2006:1) and Campbell \& Poser (2008:10) mention some of the language similarities are caused by (1) accident (chance, coincidence), (2) borrowing (language contact), (3) onomatopoeia, sound symbolism, and nursery forms, (4) universals and typologically commonplace traits, and (5) genetic relationship inheritance from a common ancestor.

In order to establish a plausible hypothesis of genetic relationship Campbell \& Poser (2008:10) suggest it is necessary to eliminate other possible explanations (1-4), and leaving a genetic relationship (5). It is the most likely the core of the generally accepted methodology for investigating possible relationships. The same argument is posed by Forston (2004:3) if two or more languages share similarities that are so numerous and systematic which do not recognize as part of the resemblances mentioned (1-4), it means that the languages are descended from the same parent language, and the languages are genetically related.

Voegelin and Voegelin (1977) and (Ruhlen 1987) as cited from Bussmann (2006:184) state that genealogical classification is based primarily on words and grammatical forms preserved in common. And the most popular method for expressing genetic relationships is the family-tree diagram consisting of the parent language as the starting point and branches indicating the descended languages (Malmkjær, 2006:288). In addition, Campbell \& Poser (2008:11) claim that plausible demonstration of genetic relationship does not in fact depend precisely on similarities among the languages compared, but rather on systematic correspondences among sounds in compared words, especially basic vocabulary, and on patterned grammatical evidence of the appropriate sort. Furthermore Campbell \& Poser (2008:11) admit that related languages can undergo so much change that they no longer appear superficially similar, but elements in them can exhibit systematic agreements which nevertheless demonstrate the relationship.

\subsection{Language subgrouping}

Crowley (1987:187) explains that subgrouping in a language family can be established by applying comparative method to determine which languages are related to other languages in the language family. The closer related languages stands as a subgroup within the language family. Thus, it is possible that within the family language there stands more than one language subgroup. Subgrouping in a family tree is, then, represented by a series of branches coming from a single point.

It sometimes makes readers, especially the beginners, of historical-comparative linguistics assume ,subgroupinge is sinonimous with, subgroup ${ }^{\text {ee }}$. But in fact, both termsmake different sense. "Subgroupingee refers to ,process ${ }^{\text {ee }}$ while ,subgroup ${ }^{\text {ee }}$ is ,result ${ }^{\text {ee }}$ of the subgrouping. The difference between ,subgroupingee and ,subgroup ce can be seen on the following quotations.

"Subgrouping is theinternal classification of languages within a language family, typically represented in a family tree; the determination of which sister languages are more closely related to one another within a language family, that is, the working out of the subgroups (branches, subfamilies). A subgroup is a group of languages within a language family that are more closely related to each other than to other languages of that family (Campbell \& Mixco, 2007:194)."

Relating to the subgroup, Hoenigswald (1960:146) offers ,regular sound changes ${ }^{\text {ee }}$ as requisite in establishing subgroup. However, Crowley (1987:188), (Reiss, 2006:240), and Campbell \& Mixco(2007:194) propose and strict on their idea that subgrup can only be established by considering ,shared innovation of the languages, namely a change that shows a departure from some trait or traits of the proto-language and is shared exclusively by a set of related languages (Campbell \& Mixco, 2007:183).

\section{Methods}

The method of this study is field linguistic or fieldwork (Samarin, 1967) to eight villages represented the eight languages in this study by using Sulawesi Umbrella wordlist consists of more than 400 words as an instruments in collecting linguistic data. The data was then analyzed by applying WordSurv ver.7 where its result was useful in setting up language subgroup and drawing language family tree.

The villages or sites of this research are (1) Gane Dalam for Gane language with three informants $(\mathrm{m}=2, \mathrm{f}=1)$; (2) Ngofakiaha for East Makian language with two informants $(\mathrm{m}=1, \mathrm{f}=1)$; (3) Wailukum for Buli language with three informants $(\mathrm{m}=2, \mathrm{f}=1)$; (4) Soagimalaha for Maba language with three informants $(\mathrm{m}=1, \mathrm{f}=2)$; (5) Banemo for Patani language with three respondents $(\mathrm{m}=2, \mathrm{f}=1)$; (6) Sagea for Sawai language with three respondents $(\mathrm{m}=1, \mathrm{f}=2) ;(7)$ Yoi for Gebe language with three informants $(\mathrm{m}=1, \mathrm{f}=2)$; and $(8)$ Kuri for Irarutu language with two informants $(\mathrm{m}=2)$.

\section{Results}

To prove the degree of genealogical relationship of South Halmahera languages in this research, the researcher analyzes linguistic data quantitatively through lexicostatisc in order to set language subgrouping and to draw language family tree.

Subgrouping is one of the evidences to proof the degree of genealogical relationship. According to Crowley (1987:190), lexicostatistics is a technique that allows us to determine the degree of relationship between two languages by comparing the vocabulary of the languages and determining the degree of similarity between them.

The first step in making subgrouping is by counting the cognates percentage of the language varieties, and the last is by visualizing the language varieties into a tree diagram

\section{Volume 5 Issue 1, January 2016}




\section{International Journal of Science and Research (IJSR) \\ ISSN (Online): 2319-7064}

Index Copernicus Value (2013): 6.14 | Impact Factor (2014): 5.611

which splits the languages based on the percentage of cognates.

In counting the percentage of cognates, the researcher applies a linguistic program, called WordSurv, a program for analyzing word lists collected in a language survey. The percentage of cognates of each language variety on WordSurv is displayed at comparison analysis tab. The comparison analysis tab presents three kinds of data: tally (number of apparent cognates); total (total number of words in each variety); and percent of cognates (tally/total). In the following are the tables of tally, total, and percent of South Halmahera languages:

Table 1: Number of Apparent Cognates

\begin{tabular}{|c|c|c|c|c|c|c|c|c|}
\hline TALLY & IR & SW & GB & BL & MB & PT & GN & EM \\
\hline IR & 410 & 61 & 68 & 59 & 63 & 62 & 59 & 61 \\
\hline SW & 61 & 421 & 196 & 212 & 260 & 280 & 176 & 147 \\
\hline GB & 68 & 196 & 428 & 184 & 204 & 218 & 147 & 134 \\
\hline BL & 59 & 212 & 184 & 445 & 309 & 273 & 147 & 124 \\
\hline MB & 63 & 260 & 204 & 309 & 430 & 347 & 150 & 125 \\
\hline PT & 62 & 280 & 218 & 273 & 347 & 456 & 175 & 145 \\
\hline GN & 59 & 176 & 147 & 147 & 150 & 175 & 426 & 206 \\
\hline EM & 61 & 147 & 134 & 124 & 125 & 145 & 206 & 410 \\
\hline
\end{tabular}

Table 2: Total Number of Words in Each Varity

\begin{tabular}{|c|c|c|c|c|c|c|c|c|}
\hline TOTAL & IR & SW & GB & BL & MB & PT & GN & EM \\
\hline IR & 411 & 368 & 376 & 386 & 376 & 393 & 374 & 364 \\
\hline SW & 386 & 421 & 396 & 407 & 402 & 419 & 401 & 384 \\
\hline GB & 376 & 396 & 430 & 416 & 403 & 421 & 401 & 386 \\
\hline BL & 386 & 407 & 416 & 445 & 428 & 438 & 414 & 395 \\
\hline MB & 376 & 402 & 403 & 428 & 431 & 428 & 406 & 385 \\
\hline PT & 393 & 419 & 421 & 438 & 428 & 458 & 420 & 404 \\
\hline GN & 374 & 401 & 401 & 414 & 406 & 420 & 426 & 385 \\
\hline EM & 364 & 384 & 386 & 395 & 385 & 404 & 383 & 411 \\
\hline
\end{tabular}

Table 3: Number of Cognates Percent in each Variety

\begin{tabular}{|c|c|c|c|c|c|c|c|c|}
\hline$\%$ & IR & SW & GB & BL & MB & PT & GN & EM \\
\hline IR & 100 & 17 & 18 & 15 & 17 & 16 & 16 & 17 \\
\hline SW & 17 & 100 & 49 & 52 & 65 & 67 & 44 & 38 \\
\hline GB & 18 & 49 & 100 & 44 & 51 & 52 & 37 & 35 \\
\hline BL & 15 & 52 & 44 & 100 & 72 & 62 & 36 & 31 \\
\hline MB & 17 & 65 & 51 & 72 & 100 & 81 & 37 & 32 \\
\hline PT & 16 & 67 & 52 & 62 & 81 & 100 & 42 & 36 \\
\hline GN & 16 & 44 & 37 & 36 & 37 & 42 & 100 & 54 \\
\hline EM & 17 & 38 & 35 & 31 & 32 & 36 & 54 & 100 \\
\hline
\end{tabular}

The percent of cognates on the table 3 above cannot be applied directly to language family tree. Firstly, it should be counted all figures of the cognates percent at every block on the table. It is easier and takes shorter steps to count the percent of cognates, if the language is below five varieties. The more languages are being compared, the more complex and longer steps in counting the average percent of cognates. In the following tabel is a simplification model of tabel 3 which is used to count the average percent of cognates of South Halmahera languages.
Table 4: A Simplification from Table 3

\begin{tabular}{|c|c|c|c|c|c|c|c|}
\hline IR & & & & & & & \\
\hline 17 & SW & & & & & & \\
\hline 18 & 49 & GB & & & & & \\
\hline 15 & 52 & 44 & $\mathrm{BL}$ & & & & \\
\hline 17 & 65 & 51 & 72 & $\mathrm{MB}$ & & & \\
\hline 16 & 67 & 52 & 62 & 81 & $\mathrm{PT}$ & & \\
\hline 16 & 44 & 37 & 36 & 37 & 42 & GM & \\
\hline 17 & 38 & 35 & 31 & 32 & 36 & 54 & EM \\
\hline
\end{tabular}

The first step is to try to find out which languages in the data are most closely related to each other. The procedure is to look for figures that are significantly higher than any other figures in the table, which is an indication that these particular languages are relatively closely related to each other (Crowley, 1987:197-198).

Table 5: A Closely Related Cognates Percent

\begin{tabular}{|c|c|c|c|c|c|c|c|}
\hline IR & & & & & & & \\
\hline 17 & SW & & & & & & \\
\hline 18 & 49 & GB & & & & & \\
\hline 15 & 52 & 44 & $\mathrm{BL}$ & & & & \\
\hline 17 & 65 & 51 & 72 & MB & & & \\
\hline 16 & 67 & 52 & 62 & 81 & PT & & \\
\hline 16 & 44 & 37 & 36 & 37 & 42 & GM & \\
\hline 17 & 38 & 35 & 31 & 32 & 36 & 54 & EM \\
\hline
\end{tabular}

The table 5 shows that the communities Maba and Patani belong to a very closely related $(81 \%)$. Communities Gane and East Makian also seem to belong together (54\%), and so too the three communities Sawai, Gebe, and Buli (average $=48 \%$ ).

The second step is to try to find out what the next level of relationship is. To make this task easier, we can now treat the subgroups we have just arrived at as single units for the purpose of interpretation. Let us, at this level, relabel the units so that it is clear that we are operating with units at a different level of subgrouping (Crowley, 1987:198).

The eight languages of this study (Buli, Maba, Patani, Sawai, Gane, Gebe, East Makian, and Irarutu) are regrouped based on their closeness of the percent of cognates shown on table 4.25. The new labels used in this step are:

$$
\begin{array}{lcc}
\text { IR } & \ldots \ldots \ldots \text { I } \\
\text { SW, GB, BL } & \ldots \ldots \ldots \text { II } \\
\text { MB, PT } & \ldots \ldots \ldots . \text { III } \\
\text { GN, EM } & \ldots \ldots \ldots \text { IV }
\end{array}
$$

The next steps in counting the average of all figures at each

\begin{tabular}{|c|c|c|c|}
\hline I & & & \\
\hline 17 & II & & \\
\hline 17 & 62 & III & \\
\hline 17 & 37 & 37 & IV \\
\hline
\end{tabular}
block on table 5 above. The result of counting is presented on the table 6 below.

Table 6: The Result of Average Counting of Cognates

Coming up to this result, treating all the figures of cognates percent at the blocks as ordinary way and looking for the

\section{Volume 5 Issue 1, January 2016}




\section{International Journal of Science and Research (IJSR) \\ ISSN (Online): 2319-7064 \\ Index Copernicus Value (2013): 6.14 | Impact Factor (2014): 5.611}

highest cognate figures as an indication of the closest degree of relationship. It seems that unit II and III are more closely related to each other than any of the other units with the figure $62 \%$, they therefore belong to a higher level subgroup.

In order to avoid confusion, combine the closest units again into a new single label, then, working out the next degree of relationship. The new labels of the regrouping languages as in the following:

I (IR)

II $(\mathrm{SW}, \mathrm{GB}, \mathrm{BL})+\mathrm{III}(\mathrm{MB}, \mathrm{PT})$

$\begin{array}{ll}\text { A } \\ \cdots \ldots \ldots \ldots \ldots \ldots & \mathrm{B} \\ \ldots \ldots \ldots \ldots \ldots \ldots & \mathrm{C}\end{array}$

IV (GN, EM)

............. C

The regrouping of unit II and III on table 6 above bears a final result visualized on the following table 7

Table 7: The Final Result of Counting the Cognates Percent of SH Languages

\begin{tabular}{|c|c|c|}
\hline A & \multicolumn{2}{l}{} \\
\hline 17 & B & \\
\hline 17 & 49 & C \\
\hline
\end{tabular}

Due to the final result of cognates percent counting above, the average of cognates percent between languages in unit $\mathrm{A}$ and $\mathrm{B}$; and between languages in unit $\mathrm{A}$ and $\mathrm{C}$ are $17 \%$ respectively; and the average cognates percent between languages in unit $\mathrm{B}$ and $\mathrm{C}$ is $49 \%$. To understand the degree of language relationship, Crowley (1987:193) explains:

... a 'family' simply refers to all languages that share between $36 \%$ and $81 \%$ of their core vocabularies. Languages in lesser degrees of relationship are not considered to be in the same family, but in the same 'stock' or 'phylum' (Crowley, 1987:193). A further detailed of language classification degree can be seen on Crowley (1987:192) as cited in the following figure:

\begin{tabular}{|c|c|}
\hline Level of Subgrouping & $\begin{array}{c}\text { Cognat percentage in } \\
\text { core vocabula }\end{array}$ \\
\hline Dialects of a language & $81-100 \%$ \\
\hline Languange of a family & $36-81 \%$ \\
\hline Families of a stock & $12-36 \%$ \\
\hline Stocks of a microphylum & $4-12 \%$ \\
\hline Microphyla of a mesophylum & $1-4 \%$ \\
\hline Mesophyla of a macrophylum & $0-1 \%$ \\
\hline
\end{tabular}

Figure 1: Level of Subgrouping (from Crowley, 1987) languages in unit $\mathbf{B}$ (Sawai, Gebe, Buli, Maba, Patani) and languages in unit $\mathbf{C}$ (Gane, East Makian) are languages of family (49\% [range between $36 \%$ and $81 \%$ ]); while language in unit A (Irarutu) with (17\%) is family of stock (range between $12 \%$ and $36 \%$ ).

Further detailed of language classification was suggested by Swadesh (1954 cf. Gudschinsky, 1964:621) in a figure below:

\begin{tabular}{|c|c|c|}
\hline Term & Divergence Century & Cognat percentage \\
\hline Language & $0-5$ & $100-81 \%$ \\
\hline Family & $5-25$ & $81-36 \%$ \\
\hline Stock & $25-50$ & $36-12 \%$ \\
\hline Microphylum & $50-75$ & $12-4 \%$ \\
\hline Mesophylum & $75-100$ & $4-1 \%$ \\
\hline Macrophylum & Over -100 & less than $1 \%$ \\
\hline
\end{tabular}

Figure 2: Level of Subgrouping (from Swadesh)

In addition, within a language family, there are languages which are more closely related to each other than to other languages of that family. This condition is explained by Campbell (1999) as in the following:

"A language family is a group of genetically related languages, that is, languages which share a linguistic kinship by virtue of having developed from a common ancestor. Language families can be of different magnitudes; that is, they can involve different time depths, so that some largerscale families may include smaller-scale families among their members or branches. The term subgroup (also called subfamily, branch) is used to refer to a group of languages within a language family which are more closely related to each other than to other languages of that family - that is, a subgroup is a branch of a family. Campbell (1999:165166)."

Considering what is stated by Campbell (1999:165-166) above and consulting to the data on table 4.25 , it shows that the language family of South Halmahera covers three subfamilies or subgroups, namely: subfamily of SawaiGebe-Buli (henceforth SGB); subfamily of Gane-East Makian (henceforth GEM); and Subfamily of Patani-Maba (henceforth PM). The subgrouping of South Halmahera languages can be drawn into a language family tree as in the following figure 4.6 .

The final counting result of cognates percent on table 7 above implies that the degree of relationship between

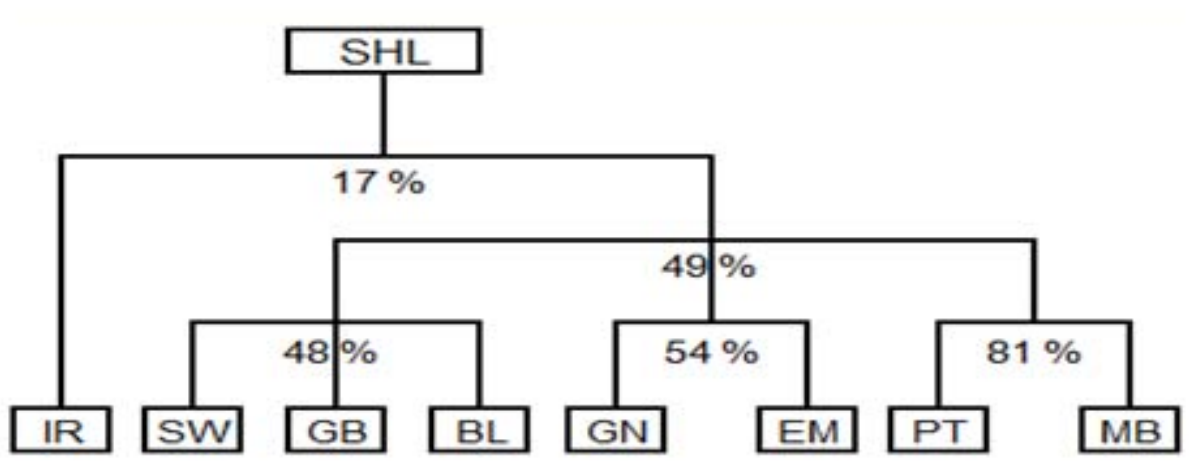

Figure 3: Language Family Tree of South Halmahera

Volume 5 Issue 1, January 2016 


\section{International Journal of Science and Research (IJSR) \\ ISSN (Online): 2319-7064 \\ Index Copernicus Value (2013): 6.14 | Impact Factor (2014): 5.611}

Looking backward to Swadesh's (1954) classification of languages on figure 4.6 above, it is tentatively predicted that the separation of South Halmahera languages with Irarutu language was dated between 25 and 50 centuries ago; while the separation of subfamilies out from South Halmahera languages family was happened between 5 and 25 centuries ago.

\section{Conclusion}

The result of quantitative approach of subgrouping South Halmahera languages bears Irarutu as a ,family of stock $^{\text {ee }}$ $(17 \%)$ which is predicted separated in $25-50$ century ago, and a ,languages of family ${ }^{e e}$ which covers seven sister languages, namely: Sawai, Gebe, Buli, Maba, Patani, Gane, and East Makian. Theses sister languages are grouped into three subfamily: subfamily of Sawai- Gebe-Buli; subfamily of Gane-East Makian; and subfamily of Maba-Patani. This subfamily were separated each other in 5-25 century ago (49\%). Due to the cognates percent of each subfamily, subfamily of Maba-Patani is categorized into ,dialect of a language ${ }^{e e}$, which implies that the speakers of two languages are mutually intelligibility.

\section{References}

[1] Aikhenvald, A. Y., \& Dixon, R. M. (Eds.). (2006). Areal Diffusion and Genetic Inheritance: Problems in Comparative Linguistics. Oxford: Oxford University Press.

[2] Anceaux, J. C. 1961. The linguistic situation in the islands of Yapen, Kurudu, Nau and Miosnum, New Guinea. Verhandelingen van het Koninklijk Instituut voor Taal-, Land-en Volkenkunde 35. "s-Gravenhage: Martinus Nijhoff.

[3] Blust, R. A. (1993). Central and Central-Eastern Malayo-Polynesian. Oceanic Linguistics 32:241-293.

[4] Blust, R. A. (2013). The Austronesian Languages. Canberra: Asia-Pacific Linguistics.

[5] Bussmann, H. (2006). Routledge Dictionary of Language. London: Taylor \& Francis e-Library.

[6] Campbell, L. (1999). Historical linguistics : an introduction. USA: MIT Press.

[7] Campbell, L., \& Mixco, M. J. (2007). A Glossary of Historical Linguistics. Edinburgh: Edinburgh University Press.

[8] Campbell, L., \& Poser, W. J. (2008). Language Classification: History and Method. Cambridge: Cambridge University Press.

[9] Collins, J. T. (1983). The Historical Relationships of the Languages of Central Maluku, Indonesia. Canberra: The Australia National University.

[10] Crowley, T. (1987). An Introduction to Historical Linguistics. Papua New Guinea: University of Papua New Guinea Press.

[11] Forston, B. W. (2004). Indo-European Language and Culture: an introduction. . USA: Blackwell Publishing Ltd.

[12] Gudschinsky, Sarah C. (1964). The ABC's of Lexicostatistics (Glottochronology). In Dell Hymes, Language in Culture and Society. A reader in Linguistics and Anthropology (pp612-623). New York: Harper and Row, Publishers
[13]Kamholz, D. C. (2014). Austronesians in Papua: Diversification and change in South Halmahera-West New Guinea. (A Ph.D Dissertation). Berkeley: University of California.

[14]Lewis, M. P., Simons, G. F., and Fennig, C. D. (Eds.). (2014). South Halmahera-West New Guinea. Retrieved July 25, 2014, from Ethnologue: Languages of the World: http://www.ethnologue.com

[15] Malmkjær, K. (2006). The Linguistics Encyclopedia. USA: Taylor \& Francis e-Library.

[16]Ross, Malcolm. (1995). Some current issues in Austronesian linguistics. In Tryon 1995, 1:45-120.

[17] Samarin, W. J. (1967). Field Linguistics: A Guide to Linguistic Field Work. New York: Holt, Rinehart and Winston.

[18] Schendl, H. (2001). Historical Linguistics. New York: Oxford University Press.

[19] Trask, L. R. (2005). Key Concepts in Langhuage and Linguistics. London: Taylor \& Francis e-Library.

[20] Van Staden, M. (2000). Tidore: A Linguistic Description of a Language of the North Moluccas. Leiden: Universiteit Leiden.

[21] Widjojo, M. (2009). The Revolt of Prince Nuku Crosscultural Alliance-making in Maluku, c.1780-1810. Leiden, The Netherlands: Koninklijke Brill NV.

\section{Author Profile}

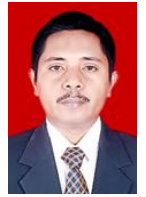

Jumahir Jamulia is an English teacher at the State Institute for Islamic Studies (IAIN) Ternate since 1999. He finished his bachelor degree (S.Pd) on English Teacher Training and Education at Khairun University in Ternate, Indonesia. In $2010 \mathrm{He}$ got his magister degree on Magister of Humaniora (M.Hum) on English Language Studies at Hasanuddin University, in Makassar, Indonesia; and in $2010 \mathrm{He}$ continued to study Linguistics with special interest on Historical and Comparative Linguistics at the same university. Now he is writing his dissertation entitled „The Genealogical Relationship of Language and Culture of South Halmahera Languages Group"e under the supervisors of Prof. Dr. H. Hamzah A. Machmoed, M.A and Prof. Drs. H. Burhanuddin Arafah, M.Hum., Ph.D. 